\title{
Wall thickness determination study for a plastic injection barrell due to the internal pressure
}

\section{Estudio para la determinación del espesor de pared adecuado para un cañón de inyección de plástico debido a la presión interna}

RODRÍGUEZ-DAHMLOW, Jesús E.†, CONTRERAS-LOPÉZ, David*，FUENTES-RAMÍREZ, Rosalba and MURILLO-YAÑEZ, Luis E.'

Universidad de Guanajuato, Chemical Engineering Department, Noria Alta s / n, Guanajuato, Gto., 36050, Mexico. 'Instituto Politécnico Nacional, Interdisciplinary Professional Unit of Engineering Campus Guanajuato, Av. Mineral de Valenciana No. 200 Fracc. Industrial Puerto Interior Silao de la Victoria, Gto., 36275, Mexico.

ID $1^{\text {st }}$ Author: Jesús E., Rodríguez-Dahmlow / ORC ID: 0000-0002-5348-6898, CVU CONACYT ID: 253005

ID $1^{\text {st }}$ Co-author: David, Conteras-López / ORC ID: 0000-0003-1384-4766), CVU CONACYT ID: 38297

ID $2^{\text {nd }}$ Co-author: Rosalba, Fuentes-Ramírez / ORC ID: 0000-0003-0520-3387), CVU CONACYT ID: 202669

ID $3^{\text {rd }}$ Co-author: Luis E., Murillo-Yañez / ORC ID: 0000-0002-4637-5671), CVU CONACYT ID: 98720

DOI: $10.35429 / J E A .2021 .25 .8 .10 .15$

Received: January 15, 2021; Accepted: June 30, 2021

\begin{abstract}
The use of Plastics is a very common activity nowadays, there are many different types of Injection Machines varying in size, the capacity of the material to inject, one of the main machines classifications is due to the injection pressure. One of the things to consider when the designing process is carried out is the factor of safety, this factor helps designers to avoid possible failures in mechanical elements of mechanisms, it provides a safety margin that aims to protect against any unexpected incident. The advantage of Simulation is that allows us to predict the behavior of elements under stress. In the Injection Process, barrels are elements subject to high pressure. This encourages analyzing wall thickness to find a suitable barrel wall thickness. The present study is focused on the design of the wall thickness, seeking reduce machining time that are required when producing the barrels that may be needed and to select the proper commercial barrel size reducing material waste.
\end{abstract}

Barrel wall thickness, Internal pressure, Factor of safety, Injection process

\begin{abstract}
Resumen
El uso de plásticos es una actividad muy común en la actualidad, existen diferentes tipos de máquinas de inyección, estas varían en: tamaño, capacidad de material a inyectar y una de las clasificaciones principal es debida a la presión de inyección. Una de las cosas a considerar cuando se realiza el proceso de diseño es el Factor de Seguridad, este factor ayuda a los diseñadores a evitar posibles fallas en elementos mecánicos o mecanismos, provee un margen de seguridad que busca proteger contra incidentes inesperados. La simulación ayuda a predecir el comportamiento de elementos sometidos a esfuerzos. En el proceso de inyección, los cañones se someten a altas presiones. Debido a lo anterior se ve la necesidad de analizar el espesor de pared a fin de encontrar un tamaño que se adecuado. El presente estudio se centra en el diseño del espesor de pared, buscando reducir tiempos de maquinado que se requieren al producir los cañones y seleccionar el tamaño comercial adecuado para disminuir el desperdicio.
\end{abstract}

Espesor de pared, Presión interna factor de seguridad, Proceso de inyección

Citation: RODRÍGUEZ-DAHMLOW, Jesús E., CONTRERAS-LOPÉZ, David, FUENTES-RAMÍREZ, Rosalba and MURILLO-YAÑEZ, Luis E.. Wall thickness determination study for a plastic injection barrell due to the internal pressure. Journal of Engineering Applications. 2021. 8-25:10-15.

\footnotetext{
* Correspondence of the Author (Email: rodrigje@ outlook.com)

$\dagger$ Researcher contributing as first author.
} 


\section{Introduction}

Injection Processes have increased during recent years, this caused work on design improvement, one of the more effective tools used is the Finite Element Method (FEM). Using FEM, parts can be tested under different conditions such as mechanical stress due to pressure. Barrels are vessels subjected to internal forces caused for pressure which is considered for this study. The barrel is a vessel structure subjected to combined loadings (normal and shear stresses) which govern their design.

By varying the wall thickness of the barrel we can propose a change in design to reduce material, this may impact the final cost of the barrel.

\section{Pressure in injection process}

Injection Machines use very high pressures to make the polymer flow inside the mold cavity, before it can be done, the material must be accumulated at the front, in the metering zone or injection Chamber (Figure 1) causes that pressure to increase at this section.

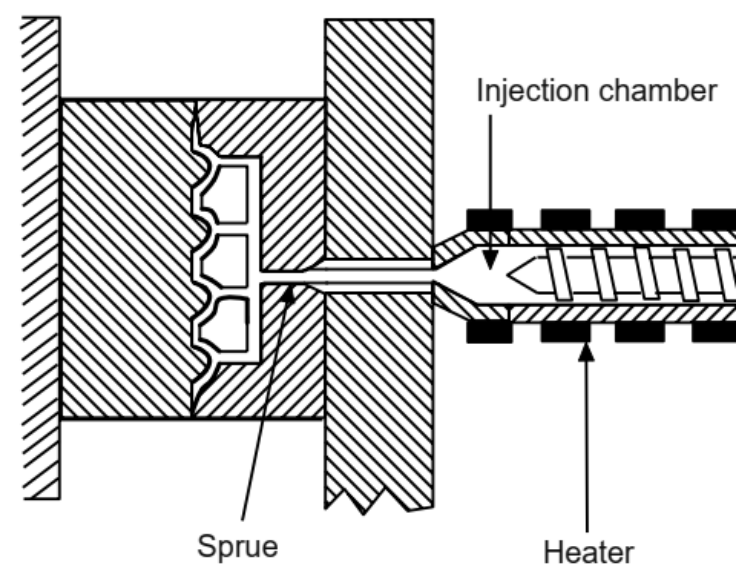

Figure 1 Bulk Material at the front of the barrel Source: (Chanda, M, 2008). [1]

Under this context, the barrel (metering zone) can be considered as a cylindrical pressure vessel that has a closed structure, these elements may contain liquids or gases under pressure. Cylindrical pressure vessels with a circular cross-section, as shown in Figure 2, are found in industrial settings (compressed air tanks and rocket motors), in homes (fire extinguishers and spray cans), and the countryside (propane tanks and grain silos).
Pressurized pipes, such as water-supply pipes and penstocks, are also classified as cylindrical pressure vessels. The geometry for the injection cylinder falls in the last examples.

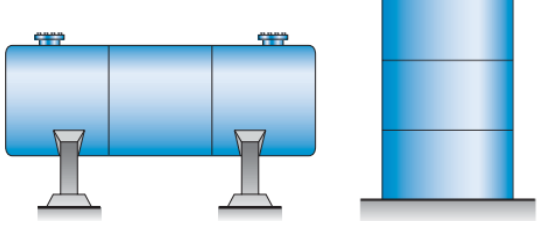

Figure 2 Cylindrical pressure vessels with a circular cross-section

Source: (Gere, J,2009), [2]

To determine the circumferential stress $\sigma 1$, we make two cuts ( $\mathrm{mn}$ and $\mathrm{pq}$ ) perpendicular to the longitudinal axis and distance $\mathrm{b}$ apart (Figure 3a). Then we make a third cut in a vertical plane through the longitudinal axis of the tank, resulting in the free body shown in Figure 3b. This free body consists not only of the half-circular piece of the tank but also of the fluid contained within the cuts. Acting on the longitudinal cut (plane mpqn) are the circumferential stresses $\sigma 1$ and the internal pressure $P$. The normal stresses $\sigma_{1}$ and $\sigma_{2}$ acting on the side faces of this element are the membrane stresses in the wall. No shear stresses act on these faces because of the symmetry of the vessel and its loading. Therefore, stresses $\sigma_{1}$ and $\sigma_{2}$ are principal stresses.

The following formula is set for the circumferential stress in a pressurized cylinder:

$\sigma_{1}=\frac{P r}{t}$

Where $P$ is the internal pressure, $r$ is the inner radius of the cylinder and $t$ is the wall thickness. This stress is uniformly distributed over the thickness of the wall. The longitudinal stress $\sigma 2$ is obtained from the equilibrium of a freebody of the part of the vessel to the left of cross section mn (Figure 3c). The stresses $\sigma 2$ act longitudinally and have a resultant force equal to $\sigma 2(2 P \mathrm{rt})$. The resultant force $P_{2}$ of the internal pressure is a force equal to $\mathrm{P} \pi \mathrm{r}^{2}$. Thus, the equation of equilibrium for the free body is

$\sigma_{2}(2 \pi r t)-P \pi r^{2}=0$ 
Solving this equation for $\sigma 2$, we obtain the following formula for the longitudinal stress in a cylindrical pressure vessel:

$\sigma_{2}=\frac{P r}{2 t}$

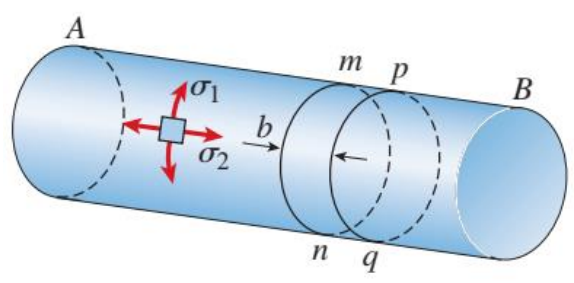

(a)

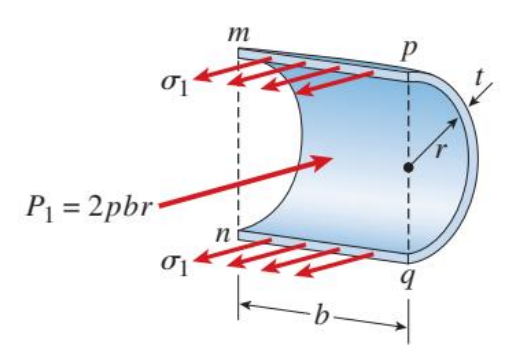

(b)

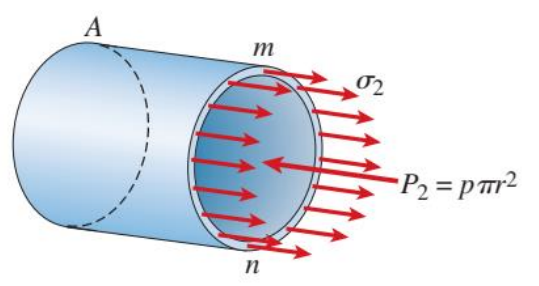

(c)

Figure 3 Principal stresses on cylindrical pressure vessels with a circular cross-section Source: (Gere, J,2009)

\section{Allowable stresses}

Factors of safety are defined and implemented in various ways. For many structures, it is important that the material remains within the linearly elastic range to avoid permanent deformations when the loads are removed. Under these conditions, the factor of safety $n$ is established concerning the yielding of the structure. Yielding begins when the yield stress is reached at any point within the structure. Therefore, by applying a factor of safety with respect to the yield stress (or yield strength), we obtain allowable stress (or working stress) that must not be exceeded anywhere in the structure [2]. Thus,

Allowable Stress $=\frac{\text { Yield strength }}{\text { Factor of Safety }}$

or $\quad \sigma_{\text {allowable }}=\frac{\sigma_{y}}{n}$
These points can be seen in the Stressstrain diagram of Figure 4 and it helps to predict the possible failure of an element among other properties.

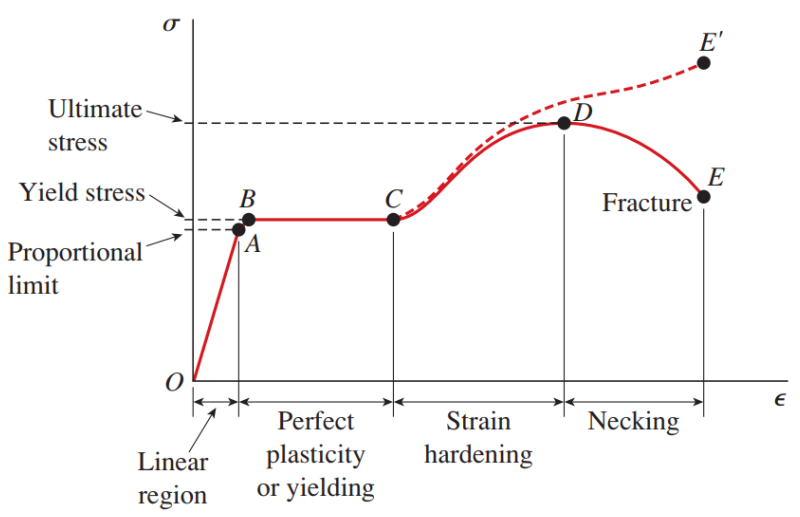

Figure 4 Stress-Strain diagram

Source: (Gere, J,2009)

\section{Finite element method}

The Finite Element Method is a technique used to predict the mechanical behaviour of elements under different loads like thermal, electrical, or mechanical. This Technique is used for numerically solving differential equations that come from the discretization of the model, create small elements connected by nodes.

Engineers are interested in evaluating effects such as deformations, stresses, temperature, fluid pressure, and fluid velocities caused by forces such as applied loads or pressures and thermal and fluid fluxes. The nature of the distribution of the effects (deformations) in a body depends on the characteristics of the force system and for the body itself. The aim is to find this distribution of the effects. For convenience, we shall often use displacements or deformations u (Figure 5) in place of effects. Subsequently, when other problems such as heat and fluid flow are discussed they will involve the distribution of temperature and fluid heads and their gradients [3]. 


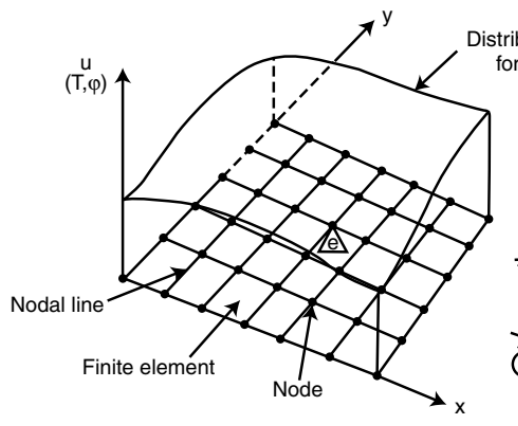

(a) stribution of $u(x, y)$

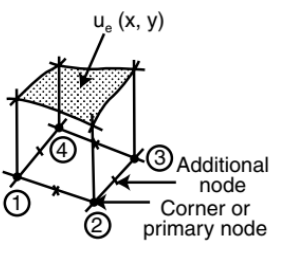

(b)
Figure 5 Distribution of displacement $\mathrm{u}$, temperature $\mathrm{T}$, or fluid head f. (a) Discretization of two-dimensional body and (b) Distribution of $\mathrm{u}_{\mathrm{e}}$ over a generic element $\mathrm{e}$ Source: (Desai, Chandrakant, 2001)

Several softwares help with the modeling of parts and assemblies, they also provide platforms for FEM analysis. Solidworks helps us to simulate the elements and try to predict their behavior showing color stripes depending on the stress intensity, where colors red and blue are the maximum and minimum stress zones (Figure 6).

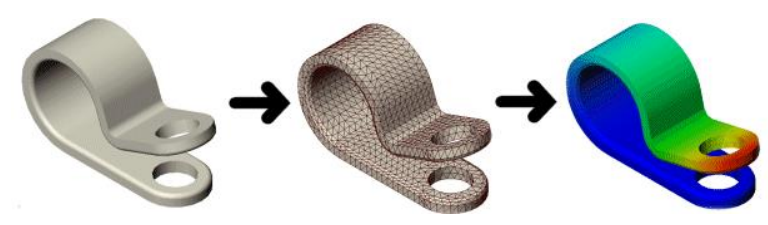

Figure 6 Element, mesh, and Stress intensity representation

Source: (Solidwoks,2020) [3]

\section{Stress analysis}

\section{Process conditions}

From previous research and applying the concept of stationary point for a function of one variable can be set the following conditions for Injection Pressure and cycle time: $8.75 \mathrm{MPa}$ and $8.607 \mathrm{~s}$ respectively [4].

The injection process is carried out by a cylindrical barrel moved by an $3 / 4 \mathrm{hp}$ electrical motor coupled a chain transmission. The material is loaded into a hoper manually and carried in the barrel by the screw rotation to the front of the barrel. Every shot uses about 19 gr of Polypropylene neglecting the process losses.
One thing to keep in mind is the heat distribution, for this work it is considered to be uniform, but it does not occur that way, there is an analysis carried out for Diaz, A which recommends a procedure to set the heat bands around the barrel (Diaz, A,2021). There is recommend waiting for 10 minutes in order to get a correct distribution of the heat in all the barrel. Another thing is the power needed for the heaters, there is shown how to make an estimation of the power consumption [5].

For this study Figure 7 represents the injection Machine used for the analysis, more accurately the Melt, here can be seen the melted material at the end of the reciprocating screw.

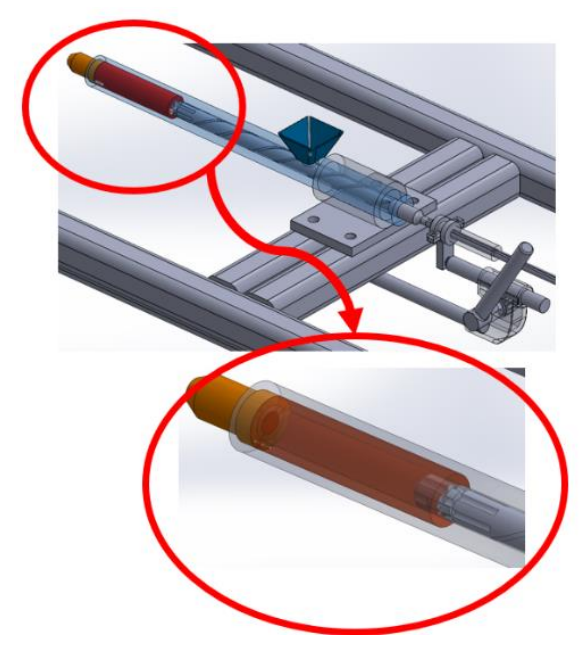

Figure 7 Material melts at the front of the barrel Source: Own work [Solidworks]

The part under analysis is selected (Domain) and to apply de FEM method discretization is needed as shown in Figure 8.
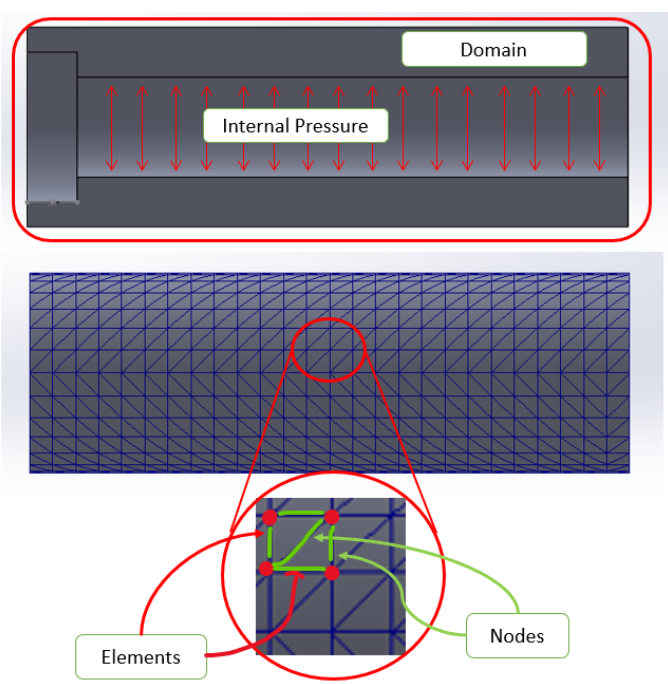

Figure 8 Domain and discretization to apply FEM Source: Own work [Solidworks] 
The Material Characteristics for the analysis are taken from the database of Solidworks using an AISI 1020 Steel, Mechanical Properties are as shown in Table 1.

\begin{tabular}{|l|r|}
\hline \multicolumn{2}{|c|}{} \\
\hline Modulus of Eleasticity E & $200 \mathrm{GPa}$ \\
\hline Poisso'n Ratio $n$ & 0.29 \\
\hline Shear Modulus of Elasticity & $77 \mathrm{GPa}$ \\
\hline Mass Density & $7900 \mathrm{~kg} / \mathrm{m}^{\wedge} 3$ \\
\hline Traction Limit & $420.5 \mathrm{MPa}$ \\
\hline Yield Stress & $35.15 \mathrm{MPa}$ \\
\hline Coefficient of thermal expansion a & $15 \times 10^{-6} / \mathrm{K}$ \\
\hline Thermal Conductivity & $47 \mathrm{~W} /(\mathrm{mK})$ \\
\hline
\end{tabular}

Table 1 Mechanical Properties for AISI 1020 Steel. Source (Solidworks,2020)

The Injection Chamber is isolated and considered a thus the different essays decreasing the wall thickness take place Figure 9.

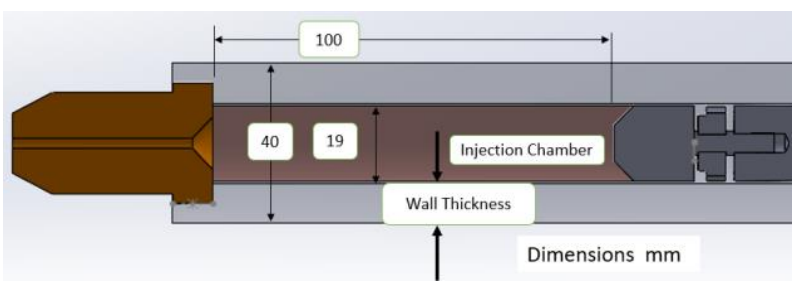

Figure 9 Wall thickness considered for analysis Source: Own work [Solidworks]

Using Solidworks software the simulation parameters and boundary conditions are set for the model as shown in Figure 10.
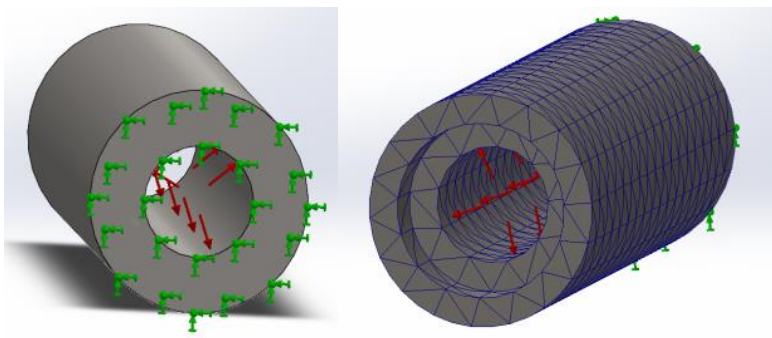

Figure 10 Model with boundary condition applied Source: Own work [Solidworks]

After all the conditions are set simulation takes place presenting the following results (Figure 11). The test was taken place reducing the wall thickness by 0.5 $\mathrm{mm}$ each time, from this we can see the results in Table 2, there are presented the Maximum Stress, displacement, and deformation for each essay.

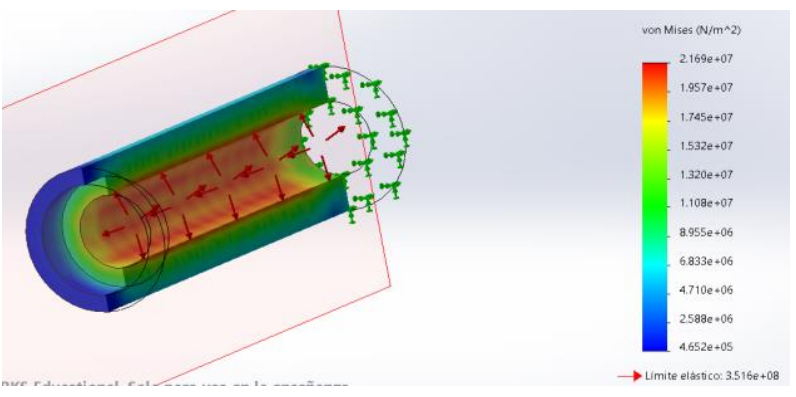

Figure 11 FEM Stress analysis results Source: Own work [Solidworks]

In Figure 12 are plotted the results for the Maximum Stress. There can be seen that at a wall thickness of $3.5 \mathrm{~mm}$ the Maximum stress is $37.7 \mathrm{MPa}$. It overpasses the stress allowable for safety conditions. Maximum stress is give in the internal wall of the barrel and it propagates through the wall thickness. Here the main stress is radial and is a combination of the pressure and the thermal expansion of the material.

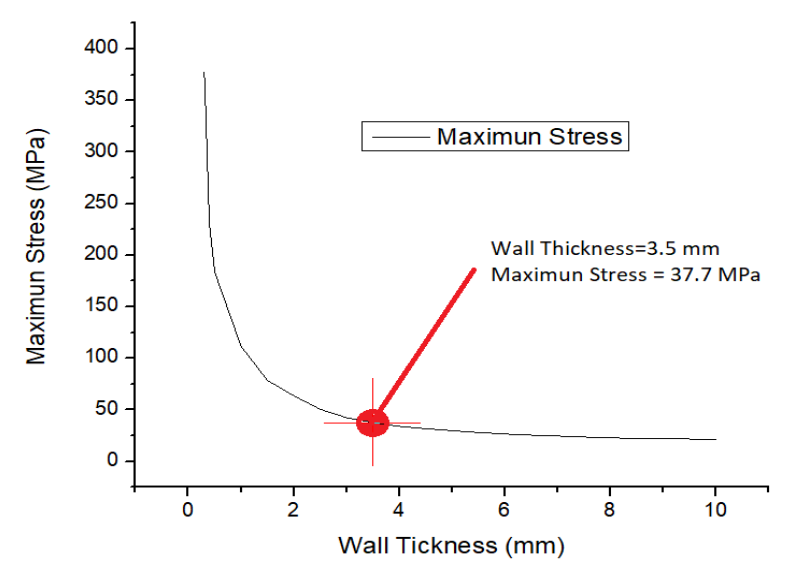

Figure 12 Wall thickness vs maximum stress diagram Source: Own work

\begin{tabular}{|c|c|c|c|c|}
\hline Essay & $\begin{array}{c}\text { Wall } \\
\text { Thickness } \\
\text { t }(\mathbf{m m})\end{array}$ & $\begin{array}{l}\text { Maximum } \\
\text { Stress } \\
\text { s (MPa) }\end{array}$ & $\begin{array}{c}\text { Maximum } \\
\text { Displacement } \\
\text { d (E-03 mm) }\end{array}$ & $\begin{array}{c}\text { Maximum } \\
\text { Deformation } \\
\epsilon(\mathrm{E}-06 \\
\mathrm{mm} / \mathrm{mm})\end{array}$ \\
\hline 1 & 10 & 21.22 & 1.183 & 74.87 \\
\hline 2 & 9.5 & 21.69 & 1.242 & 76.47 \\
\hline 3 & 9 & 22.33 & 1.311 & 79.33 \\
\hline 4 & 8.5 & 22.2 & 1.382 & 81.43 \\
\hline 5 & 8 & 22.97 & 1.47 & 83.76 \\
\hline 6 & 7.5 & 23.71 & 1.569 & 87.51 \\
\hline 7 & 7 & 24.61 & 1.687 & 92.27 \\
\hline 8 & 6.5 & 25.57 & 1.826 & 96.97 \\
\hline 9 & 6 & 26.68 & 1.995 & 101.2 \\
\hline 10 & 5.5 & 28.06 & 2.206 & 107.6 \\
\hline 11 & 5 & 29.77 & 2.465 & 114.7 \\
\hline 12 & 4.5 & 31.82 & 2.76 & 121.6 \\
\hline 13 & 4 & 33.95 & 3.138 & 132.9 \\
\hline 14 & 3.5 & 37.7 & 3.63 & 137.1 \\
\hline 15 & 3 & 42.44 & 4.308 & 155.8 \\
\hline 16 & 2.5 & 50.63 & 5.218 & 181.7 \\
\hline 17 & 2 & 63.78 & 6.636 & 221 \\
\hline 18 & 1.5 & 78.6 & 9 & 292.7 \\
\hline 19 & 1 & 111.8 & 13.21 & 419.9 \\
\hline 20 & 0.5 & 183.6 & 23.23 & 731.4 \\
\hline 21 & 0.4 & 231.1 & 26.64 & 891 \\
\hline 22 & 0.325 & 347.5 & 43.88 & 1265 \\
\hline 23 & 0.3 & 378.5 & 47.64 & 1384 \\
\hline
\end{tabular}

Table 2 Essay Results for the injection chamber Source: Own work [Solidworks]

RODRÍGUEZ-DAHMLOW, Jesús E., CONTRERAS-LOPÉZ, David, FUENTES-RAMÍREZ, Rosalba and MURILLO-YAÑEZ, Luis E. Wall thickness determination study for a plastic injection barrell due to the internal pressure. Journal of Engineering Applications. 2021 


\section{Results and Discussion}

If the factor of safety $(n)$ is set at 1.5 the $\sigma_{\text {allowable is: }}$

$\sigma_{\text {allowable }}=\frac{\sigma_{y}}{n}=\frac{35.15 M P a}{1.5}$

$=23.43 \mathrm{MPa}$

For this $\sigma_{\text {allowable }}$ the wall thickness would be $7.5 \mathrm{~mm}$ which results in a Maximum Stress of $23.71 \mathrm{MPa}$, this is a conservator value for the barrel.

The graph in Figure 13 shows the relation for a factor of safety from 1 to 1.5 . If the safety factor is set at 1 the wall thickness could be reduced to $3.5 \mathrm{~mm}$ but the failure margin is risky. On the other hand, if the value of 1.5 is considered for the wall thickness it will be very close to $\sigma_{\text {allowable }}$ but this ensures that our barrel won't fail. Another thing to keep in mind is the fact that there's still the Strain Hardening zone which helps us prevent any possible unexpected failure.

It is recommended to reduce the wall thickness due to its relation to the barrel weight, this may impact the budged required for further designs and productions of injection barrels.

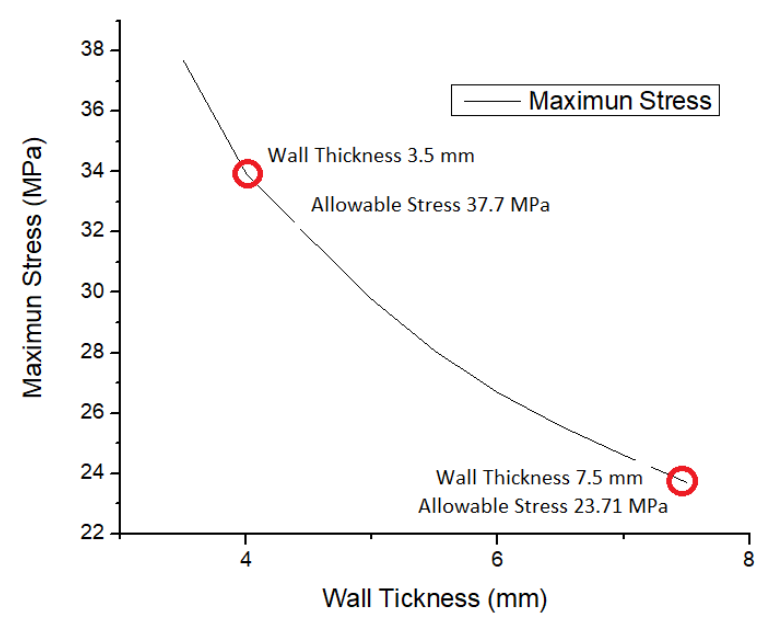

Figure 13 Factor of safety vs Allowable Stress diagram Source: Own work.

Another thing to keep in mind is that to reduce the wall thickness material must be removed and this requires time and manufacturing cost so the most proximal outer diameter must be selected and considering also the original internal diameter for commercial tubes.
Simulation helps to find a starting point for the design of machines and mechanisms, the main points to keep in mind are: what kind of material are we working with, work conditions, material imperfections. The simulation also is a recommendable tool due to it doesn't require buying any material or machining. The parameters can be changed easily. The issues are computing time, computer and software requirements, and the understanding of the theory related to the phenomena. After developing the present

\section{References}

1) Chanda, M. and Salil, R. (2008). Plastic Fabrication and Recycling, CRC Press.

2) Gere, J. (2009). Tension, compression, and share. Mechanics of Materials (4344). USA: Cengage.

3) Chandrakant, S. (2001). Introductory Finite Element Method. US: CRC Press LLC.

4) Rodríguez, J. (2020). Injection parameters study for a polypropylene probe used on tension test. Volume 7 Number 20, pages 1-6, ECORFANMéxico, S.C.

5) Diaz Maldonado, A. A. \& Rivera Ponce, S. R. (2021). Desarrollo de un sistema de automatización industrial aplicado a una máquina de moldeo por inyección para elaborar y enfriar piezas de plástico de polietileno de alta densidad. Universidad Peruana de Ciencias Aplicadas. Peru. 